\title{
JULIÁN DE TOLEDO, LOS JUDÍOS Y EL JUDAÍSMO
}

\section{JULIAN OF TOLEDO, THE JEWS, AND JUDAISM}

\author{
Céline MarTin* \\ Université Bordeaux-Montaigne / Institut Ausonius
}

RESUMEN. Este trabajo examina la relación que guardan las obras de Julián de Toledo († 690) con los judíos y la religión judía. El obispo toledano pudo verse aquejado por un doble problema original: su procedencia familiar judía, percibida por él, como por el resto de la sociedad, como una verdadera alteridad, independientemente de su fe cristiana; y su apoyo al conde Ervigio en la deposición del rey Wamba en 680. Tanto su procedencia como su traición pudieron atormentar a Julián, que colaboró estrechamente en la política antijudaica de Ervigio. En su obra histórica al menos, «judío» y «traidor» vienen a ser conceptos intercambiables, lo cual incita a cuestionar las menciones que él hace a los judíos de la provincia Narbonense.

PALABRAS CLAVE: España visigoda, Julián de Toledo, relaciones judeo-cristianas, política altomedieval, alteridad.

ABSTRACT. This paper discusses the relation between the works of Julian of Toledo (d. 690), the Jews, and the Jewish religion. Julian may have suffered from a twofold stigma: his Jewish familiar background, which quite apart of his Christian faith he must have perceived, as did the rest of Iberian society, as a real otherness, and his support to Count Ervig in overthrowing King Wamba in 680. His procedency as well as his treason could be a cause of torment to Julian, who played a major part in Ervig's anti-Jewish policy. In his historical works, "Jewish» and "traitor» are concepts deeply associated, which induces to take with caution the mentions he makes to the Jews of the Narbonensis province.

KEYWORDS: Visigothic Spain, Julian of Toledo, Jewish-Christian relations, Early medieval politics, otherness.

\footnotetext{
* Correspondencia a / Correspondence to: Céline Martin, Université Bordeaux-Montaigne / Institut Ausonius, Maison de I'Archéologie. 8, Esplanade des Antilles. 33607 Pessac (Francia) - celine.martin@u-bordeaux-montaigne.fr - https://orcid.org/0000-0003-4510-2062.

Cómo citar / How to cite: Martin, Céline (2020), "Julián de Toledo, los judíos y el judaísmo», Veleia, 37, 211-226. (https://doi.org/10.1387/ veleia.20915).
}

Recibido: 5 junio 2019; aceptado: 14 octubre 2019.

ISSN 0213-2095 - elSSN 2444-3565 / (C) 2020 UPV/EHU 
Julián de Toledo, metropolitano de la sede regia visigoda de 680 a 690, ocupó un lugar destacado en la lucha del régimen contra el judaísmo a través de la teología y la ley. Sus obras teológicas nos son conocidas gracias al catálogo proporcionado por su biógrafo y sucesor, Félix de Toledo (Vita s. Iuliani, 7-11). Tres de ellas tienen un propósito polémico contra los judíos: el De comprobatione sextae aetatis ('Demostración de que el mundo se halla en su sexta edad'), dedicado al rey Ervigio, el Antikeimenon libri duo ('Dos libros sobre las contradicciones'), y un Liber responsionum ('Libro de respuestas'). El primero desmonta el cómputo judío de las edades del mundo, afirmando que 686 se corresponde con 6011, es decir, que el mundo no se encuentra en su quinta edad, a la espera del Mesías, sino ya en su sexta. El segundo, escrito también cerca de 686, busca explicar la contradicción entre Antiguo y Nuevo Testamento, otro argumento habitual de los judíos de la Tardoantigüedad para negarle a Cristo el carácter de Mesías. El tercero, el Libro de respuestas, no se ha conservado. Según refiere Félix de Toledo, no iba dedicado al rey, sino al obispo Idalio de Barcelona, y defendía las normas civiles y canónicas que prohibían a los judíos tener esclavos cristianos ${ }^{1}$.

El manuscrito del siglo x a través del cual nos llegó el Antikeimenon viene dedicado a un princeps sin nombrar. Tanto esta obra como el De comprobatione, donde Julián sí nombraba a Ervigio, ofrecía al monarca, desde el cómputo y la exégesis bíblica, un armazón conceptual para sostener su legislación antijudaica anterior. En efecto, escasos meses después de su acceso al trono en octubre 680, Ervigio había promulgado una nueva versión del código de leyes visigótico, el Liber Iudiciorum, añadiendo un pequeño libro (libellus) de veintiocho novelas titulado Sobre las novelas de los judios, por donde se confirman las antiguas leyes y se añaden nuevas ${ }^{2}$. Se trataba de crear un marco jurídico para un nuevo bautismo forzado de los judíos del reino que debía celebrarse antes de un año y de castigar las desviaciones de los «conversos». Unos años más tarde, en el prefacio del De comprobatione sextae aetatis que dedicó al rey Ervigio, Julián expondría la relación que les unía a ambos en este asunto: comparando el judaísmo con una gangrena, afirmaba que incumbía al monarca «apartar el pus mortal de los miembros inútiles y las heces purulentas de la piel insanable» para que el resto del cuerpo no enfermase, mientras a él, Julián, le tocaba cuidar de los miembros que aún permanecían sanos ${ }^{3}$. Esta frase, con toda su crudeza, implica que el libro de Julián no estaba dirigido a los judíos, sino a los cristianos; contra los primeros, dejaba que el rey manejase «el hierro para prevenir la purulencia de la herida» ${ }^{4}$. Pero Julián no solo apoyó la legislación antijudaica de su real socio: muy probablemente participó en su elaboración, tal como manifiesta un estudio pormenorizado de su estilo. Yolanda García López observa numerosos "paralelismos de construcción, expresiones e ideas» entre la Historia Wambae, los Concilios XII y XIII de Toledo y las leyes ervigianas, «síntoma de que detrás de todas ellas está la misma mano»5.

1 Item librum responsionum ad quem supra directum in defensione canonum et legum, quibus prohibentur christiana mancipia dominis infidelibus deseruire (Felix Toletanus, Vita s. Iuliani, 7, ed. V. Yarza Urquiola 2014, 12).

2 De nouellis legibus iudeorum, quo et uetera confirmantur, et noua adiecta sunt (Liber Iudiciorum = LVXII, 3). Cf. King 1972, 133-146.

3 Qui dum populos a Deo tibi creditos contingi exitio lethali formidas, utile praecisionis genus excogitas, quo exitiabilem membrorum inutilium saniem, et purulentae fae- cis insanabilem cutem, remediabili queant hi, qui saluandi sunt, studio declinare. Quam ob causam sanis adhuc membris me praecipitis impendere curam, ne quandoque morbis accidentibus decidant, ut ante praecidatur error, quam periclitationis generetur occasio (Julianus Toletanus, De comprobatione, Praefatio, ed. Hillgarth 1976, 145).

4 Peritorum mos est iste medicorum, ubilibet uulnus serpit in corpore, ferro uulneris materiam praeuenire (ibid.).

5 García López 1996, 229. La autora expone unos ejemplos pp. 230-232. 
En definitiva, tal como se ha advertido ya incontables veces, Julián de Toledo, aun enraizando su producción escrita en la tradición isidoriana e ildefonsiana, le dio un enfoque marcadamente antijudaico, tanto en su vertiente teológica como en su apoyo a las normas civiles y canónicas emitidas desde Toledo. Procediese del rey Ervigio o de él mismo la preocupación de reprimir a los judíos a través de la ley (probablemente fuera compartida por los dos, pero no por el predecesor de Ervigio, Wamba, del que se ha observado que, llamativamente, no legisló contra los judíos), está claro que Julián sentía cierta obsesión personal por el judaísmo y los judíos. Su propio origen es una explicación obvia a dicha obsesión.

Por lo que se puede saber de su procedencia y de su carrera eclesiástica, Julián fue un advenedizo. Información sobre sus orígenes solo nos proporcionan dos fuentes, la Vita escrita por su sucesor Félix de Toledo y la Chronica de 754. De acuerdo con la segunda,

En ese tiempo es famoso en el mundo entero, por su enseñanza sobre Cristo, el obispo Julián, salido de cepa judía [ex traduce Iudeorum], como flores de rosa entre matorrales de espinas. Había nacido también de padres cristianos y recibió una educación espléndida en todas las ciencias en Toledo, donde posteriormente fue adornado con el episcopado. ${ }^{6}$

Esta mención al origen judío de Julián no está corroborada por ninguna otra fuente, pero actualmente los especialistas la dan por buena ${ }^{7}$. Desde luego parecería extraño que el autor anónimo de la crónica que tanta admiración profesaba por Julián de Toledo ${ }^{8}$ le hubiese denigrado sin fundamento consignando en su relato una información de este tipo. Quisiera detenerme sobre el detalle de la noticia. Según el anónimo de 754, Julián no era converso, sino descendiente de conversos: sus padres eran "cristianos». A menos de admitir que en unos pocos decenios de dominación musulmana se hubiera puesto fin a la costumbre de las fuentes visigodas de llamar sistemáticamente «judíos» a los cristianos nuevos? 9 , procedería retrasar la conversión familiar al menos a la generación anterior. Considerando que Julián nació en torno a (o poco antes de) $642^{10}$, es bastante probable que el bautismo forzoso decretado por Sisebuto en 615 o principios de $616^{11}$ fuera el origen de la conversión de sus abuelos. No lo criaron sus progenitores: lo entregaron a la catedral de Toledo, donde recibió el bautismo y fue educado desde su más tierna infancia (ab ipsis rudimentis infantiae), según afirma su sucesor en la sede y biógrafo, Félix de Toledo, sin mencionar ningún origen judío ${ }^{12}$. Ya que parece verosímil que sus padres fueran de la generación siguiente al bautismo

6 In cuius tempore iam Iulianus episcopus, ex traduce Iudeorum ut flores rosarum de inter uepres spinarum productus, omnibus mundi partibus in doctrina Xpi manet preclarus, qui etiam a parentibus Xpianis progenitus splendide in omni prudentia Toleto manet edoctus, ubi et postmodum in episcopio extitit decoratus (Chr. 754, 31, ed. Gil 2018, 344). (Todas las traducciones al castellano son nuestras).

7 Murphy 1952, 5. Desde 1952 la idea ha venido siendo aceptada por la mayoría (Martín Iglesias 2010b, 155).

8 «...Julián de Toledo, a quien parece admirar por encima de los demás» (Martín Iglesias 2010a, 244).

\footnotetext{
9 Laham Cohen \& Pecznik 2016. Una excepción reveladora aparece en las Etimologías, VIII, 10, 4, donde Isidoro invoca al Apóstol para rebatir que se pueda llamar «judía» a una persona bautizada: la objeción misma remarca que la terminología habitual en su época era la opuesta.

$10 \mathrm{La}$ edad canónica para ser diácono era 25 años y Julián fue consagrado en 667: cf. Murphy 1952, 5.

11 Sobre la fecha del bautismo forzoso de Sisebuto, véase recientemente González Salinero 2000, 28 y Dumézil 2005, 285.

12 ...in eiusdem urbis principali ecclesia sacrosancti baptismatis fluentis est lotus, et illic ab ipsis rudimentis infantiae enutritus (Felix Toletanus, Vita s. Iuliani, 1, ed. V. Yarza Urquiola 2014, 9).
} 
forzoso, la asignación de Julián a la escuela catedralicia nada tuvo que ver con el canon 60 del IV Concilio de Toledo (633), que mandaba alejar a los hijos de padres judíos para evitar que estos les contagiasen sus errores ${ }^{13}$, tanto más cuanto su letra preveía la entrega a monasterios o a seglares piadosos, no a una catedral. ¿Cómo interpretar la oblación de Julián por sus padres? En clave social, puede que ellos buscasen afianzar la privilegiada posición familiar anterior a la conversión ${ }^{14}$, tejiendo un vínculo estrecho con la catedral mediante el don de un hijo. También, y no es incompatible, pudo ser una marca ostentosa de devoción por su parte, una forma de demostrar que la educación que ellos habían recibido en un hogar cristiano o un monasterio había dado sus frutos; una forma de intentar borrar la mancha original que seguía aquejándoles, y de la que da fe una ley de Recesvinto:

Si una mentira descubierta ante los hombres provoca la infamia e irroga perjuicios [a su autor], con cuánta más razón el que ha llegado a ser falaz en la fe divina no deberá bajo ningún concepto ser admitido a prestar testimonio. Por ello se ha prohibido legítimamente a los judíos testificar, tanto a los bautizados como a los que no lo están. En cuanto a sus descendientes, si se consideran idóneos por la probidad de sus costumbres y la plenitud de su fe, se les dará verídica licencia de testificar entre los cristianos, aunque no antes de que un obispo, el rey o un juez aprueben completamente sus costumbres y su fe. ${ }^{15}$

Casi ninguna ley recogida en el Liber Iudiciorum conserva su fecha, pero su autoría y la fecha de promulgación del Liber (654) sitúa esta entre 649 y 65416, unos años después del nacimiento y la oblación de Julián a la catedral. Antes de su promulgación, ¿disponían los hijos de los judíos bautizados a la fuerza de alguna vía para evidenciar su «idoneidad»? La oblación de sus propios descendientes pudo ser una.

En definitiva, por mucho que el cronista mozárabe llamase «cristianos» a los padres de Julián, su «espinoso» origen se recordaba aún a mediados del siglo virI; con más razón, el propio Julián debió vivir con la conciencia de haber nacido en un zarzal, y, de alguna forma, la voluntad de convertirse a sí mismo en rosa. Como hemos señalado antes, en el siglo vir hispano la palabra Judaei designaba, no solo a los judíos no bautizados y a los apóstatas, sino también a todos los cristianos nuevos ${ }^{17}$. Al contrario de lo que uno podría suponer, el vocablo tenía un sentido marcadamente ét-

13 Judaeorum filios uel filias, ne parentum ultra inuoluantur erroribus, ab eorum consortio separari decernimus deputatos aut monasteriis aut Christianis uiris ac mulieribus Deum timentibus, ut sub eorum conuersatione cultum fidei discant atque in melius instituti tam in moribus quam in fide proficiant. (Conc. Tol. IV, c. 60, CCH vol. V, 238). Este canon lo analiza, con la bibliografía pertinente, González Salinero 2000, 105-107.

14 García Moreno da por hecho que Julián procedía de «una importante familia toledana de judeoconversos» (García Moreno 1993, 125), aunque nada en las fuentes permite afirmarlo con seguridad.

15 Si coram hominibus reppertum mendacium et infamem facit et damnis adfligit, quanto magis in diuina fallax fide peruentus non erit penitus ad testimonium admittendus. Merito ergo testificari proibiti sunt Iudei, seu baptizati, siue non extiterint baptizati. De stirpe autem illorum progeniti si morum prouitate et fidei plenitudine habeantur idonei, permittitur illis inter christianos ueredica quidem testificandi licentia, sed non aliter, nisi sacerdotem, regem uel iudicem mores illorum et fidem omnimodis conprobantes (LVXII, 2, 10).

16 Ninguna ley del Liber Iudiciorum conserva la autoría conjunta de Chindasvinto y Recesvinto, a pesar de haber reinado juntos de 649 a 653, mientras el enorme número de leyes atribuidas a Recesvinto solo en unos pocos meses resulta inverosímil (cf. Martin 2011, 27). Como otras tantas, la ley $L V$ XII, 2, 10 pudo ser dictada antes de la muerte de Chindasvinto, pero no antes de 649.

17 Orlandis 1980, 166; González Salinero 2000, 82-83. Sobre los distintos sentidos otorgados a la palabra Judaei en la legislación visigoda, véase Laham Cohen \& Pecznik 2016, 150 ss. 
nico ${ }^{18}$. Lógicamente, a los judíos también se les definía como seguidores de una religión (o tal vez más exactamente, de una falta de religión), pero hay que guardar en mente que el sentido religioso no predominaba nítidamente sobre el sentido étnico, más bien al contrario. Como consecuencia, por muy ortodoxa o «idónea» que se mostrase una persona de procedencia judía reciente, la mancha de su origen no era un dato fácil de descartar, y esta mancha, obviada por Félix de Toledo en su Vita, debió pesar sobre la conciencia de nuestro autor.

Para describir la procedencia de Julián, el cronista de 754 escogió una palabra poco común, tra$d u x$. Los autores antiguos la usaban en dos tipos de contextos: el agronómico y el religioso. En sentido literal, tradux es un 'brazo de vid conducido en cordón para unir cepas ${ }^{19}$ ' o una 'rama acodada para su reproducción ${ }^{20}$ ' (técnica de reproducción por acodo, en la que la rama enterrada echa raíces, naciendo así una cepa nueva por propagación vegetativa). En su sentido figurado, no menos interesante, refiere la extracción, la descendencia, así como, específicamente, la transmisión hereditaria del pecado original (Niermeyer, 1037; Blaise, 921). Ese término ya lo había empleado Ildefonso de Toledo, junto con un elenco de sinónimos, para reivindicar la pertenencia cristiana de María a pesar de ser "de cepa judía ${ }^{21}$. Se trata, pues, de una palabra "cargada», que el autor anónimo de la Crónica de 754 no elegiría al azar. De igual modo que la comparación con un rosal, el uso de tradux evoca un trasfondo vegetal, pero también alude a la doble pertenencia de la Virgen, carnalmente hebrea y espiritualmente cristiana $^{22}$ : asimismo, al tiempo que señala la mácula que afectaba a Julián, lo exime de ella, y enlaza deliberadamente su relato con la tradición teológica toledana que Julián prosiguió después de Ildefonso. Con todo, para el joven que estudió en la escuela episcopal de Toledo, a los 18 años eligió no volver al siglo ${ }^{23}$ y fue consagrado diácono en 667, esos orígenes debieron suponer un serio obstáculo de cara a completar una carrera eclesiástica ambiciosa. Sin embargo, sabemos que Julián consiguió superar ese obstáculo y recibió la consagración episcopal, en sustitución del difunto Quirico de Toledo, el 29 de enero de 680.

Para entender el contexto de esa elección inesperada, resultan de interés los dos párrafos que dedicó Félix de Toledo a los estrechos vínculos que unieron desde la niñez a Julián con su compañero (socius), el diácono Gudila. Según la Vita escrita por Félix hacia 693, poco después de su muerte, Julián había estado profundamente unido a Gudila, hasta el punto que ambos compartían un solo corazón y una sola alma ${ }^{24}$. Julián y Gudila quisieron ingresar en un monasterio que no concreta

18 Cf. Laham Cohen 2012, 9: «el carácter judío, adquirido en el nacimiento, parece tornarse indeleble». Formulé explícitamente la tesis del carácter étnico de la etiqueta «judíos» en época visigoda en Martin 2017.

19 "A side-branch of a vine trained across the space between trees in a vineyard" (Oxford Latin Dictionary, 1957).

20 «CABEZA [...] Echar de cabeza las vides y otras plantas. Es, sin cortarlas de sus cepas, volverlas a enterrar, para que arraiguen y hagan barbas en la tierra, y poderlas después cortar y trasplantar a otra parte. Lat. Rumpos, vel traduces vitium in scrobibus deponere." (Diccionario de Autoridades, vol.2, 1729, 22).

21 Quid dicis, Indaee, quid proponis, quid adstruis, quid obicis, quid obiectas? Ecce uirgo nostra ex stirpe tua est, ex genere tua est, ex radice tua est, ex traduce tua est, ex gente tua est, ex populo tua est, ex plebe tua est, ex na- tione tua est, ex origine tua est. Verumtamen ex fide nostra est, ex credulitate nostra est, ex adsensu nostra est, ex reuerentia nostra est, ex honorificentia nostra est, ex laude nostra est, ex glorificatione nostra est, ex dilectione nostra est, ex amore nostra est, ex praedicatione nostra est, ex praeconio nostra est, ex defensione nostra est, ex uindicatione nostra est (Hildefonsus Toletanus, De virginitate Sanctae Mariae, ed. Yarza Urquiola 2007, 165-166).

22 Un análisis más detenido de este pasaje de Ildefonso en Martin 2017, 320.

23 De acuerdo al canon 1 del II Concilio de Toledo de 531, llegados a los 18 ańos los oblatos de las escuelas episcopales debían elegir por sí mismos permanecer en el clero o volver al siglo ( $C C H$, vol.IV, 347-349).

24 Felix Toletanus, Vita s. Iuliani, 2-3, ed. V. Yarza Urquiola 2014, 9-10. Véase la traducción por Martín Iglesias 2011, 217. 
Félix, pero su común voluntad se vio frustrada ${ }^{25}$. Ahora bien, posiblemente la vida ascética no fuese lo que más llamaba a los dos clérigos toledanos. En la segunda mitad del siglo viI, el monasterio más sonado en las inmediaciones de Toledo era el de Agalí, un centro intelectual importante y un vivero de obispos ${ }^{26}$. Cuatro metropolitanos anteriores habían profesado en Agalí antes de ser consagrados obispos de Toledo: Eladio (615-633), Justo (633-636), Eugenio I (636-646) e Ildefonso $\left(657-667^{27}\right)$. Sabemos que Julián llegó finalmente a obispo y tenemos datos para sospechar que Gudila iba a serlo, de no haber muerto de forma prematura; en otros términos, posiblemente ambos buscaran ingresar en Agalí con vistas a acceder, algún día, a la sede episcopal toledana. Gudila iba camino de lograrlo, pues un arcediano de Toledo llamado Gudila suscribió las actas del XI Concilio de Toledo en 675:

Gudila, arcediano de la iglesia toledana de Santa María de la sede regia, firmé estas actas sinodales definidas por nosotros. ${ }^{28}$

Su suscripción figura en último lugar de las de los diáconos uicarii episcoporum (sustitutos de obispos ausentes), pero resulta muy peculiar: no se menciona que esté representando a ningún obispo, en teoría único motivo posible para que un diácono firme las actas de un concilio visigodo, y el formulario difiere del de la suscripción de los vicarios episcopales. Los otros diáconos «firman consintiendo" (consentiens subscripsi) las actas, Gudila en cambio, como cualquier obispo o abad, participa de la "definición» de las mismas y se engloba en el «nosotros» de los padres conciliares. La explicación más simple es que se encontraba asistiendo al obispo Quirico de Toledo, que por su estado físico o mental, no estaba en condiciones de presidir ese concilio provincial ${ }^{29}$, pero sí estaba presente y suscribió las actas, por lo que el arcediano no podía decirse agens uice episcopi. Este detalle indica que Gudila pudo ejercer el mismo papel durante cinco años más ${ }^{30}$, hasta su propia muerte el 8 de septiembre $679^{31}$; Quiricus tardó en morir unos meses más, hasta el 16 de enero siguiente. La situación recuerda los últimos días del obispo Masona de Mérida: viendo llegar su fin, llamó a su arcediano Eleuterio y le encomendó el cuidado de su grey mientras él se preparaba a morir. Viéndose ya obispo, Eleuterio se comportó con tal soberbia que una oración de Masona acabó con su vida al tercer día (Vitas Sanctorum Patrum Emeritensium, V, 13). No sabemos si

25 ...quique diuino efflante spiritu theoreticae, id est contemplatiuae quietis, delectati sunt perfrui bono et monasticae institutionis constringi repagulo. Sed quia aliter in superni numinis fuit iudicio, eorum est nihilominus frustrata denotio. (Ibid., 2-3).

${ }^{26}$ Linage Conde 1973, 39, n. ${ }^{\circ} 18$. Moreno Martín 2011, 209-210.

${ }^{27}$ En su De Viris, Ildefonso de Toledo, el último de ellos, dedica noticias a los tres primeros (Ildefonsus Toletanus, De Viris Illustribus, 6, 7 y 12). Notemos, sin embargo, que Ildefonso atribuye las mismas aspiraciones ascéticas frustradas a Eugenio II de Toledo (646-657), que no era egresado de Agalí, y al que Julián reconoce como "su maestro»: este apunte de Félix tal vez responda a un topos propio de los obispos toledanos y no a un deseo real por parte de los dos jóvenes.
${ }_{28}$ Gudila ecclesiae Toletanae Sanctae Mariae regiae sedis arcediaconus haec gesta synodica a nobis definita subscripsi (CCH, vol.VI, 133).

${ }^{29}$ El hecho de que Toledo XI sea un concilio provincial no justifica la suscripción de Gudila: entre los suscriptores de la asamblea de 655 (Toledo IX), también provincial, no se encuentra la del arcediano $(\mathrm{CCH}$, vol.V, 513-514).

${ }^{30}$ La senilidad de Quirico también explicaría que Wamba recurriera al metropolitano Stephanus de Mérida para ordenar obispos nuevos en la provincia eclesiástica de Toledo, tal como señala enigmáticamente el canon 4 de Toledo XII.

31 Igitur dininorum iudiciorum dispensatione, sanctae recordationis Gudila diaconus sexto idus septembres funestae mortis euentu, anno octauo Vuambanis principis, sub digna confessione diei clausit supremi curriculum (Felix Toletanus, Vita s. Iuliani, 3, ed. V. Yarza Urquiola 2014, 10). 
la muerte de Gudila fue un castigo divino por su arrogancia, pero sí resulta claro que fue un evento inesperado que debió sumir la iglesia toledana en la confusión, con un metropolitano tal vez moribundo, seguramente incapaz de llevar el gobierno episcopal, y un presunto sucesor desaparecido prematuramente.

Sin embargo, siempre siguiendo a Félix de Toledo, Julián resultó ser el hombre de la situación. Él (y no el obispo Quirico) presidió al solemne funeral del ex-futuro obispo Gudila en un monasterio próximo a la capital, San Félix, fundado en una finca llamada Cabensis $^{32}$, y que no aparece mencionado en otras ocasiones en la documentación. Cuatro meses después, muerto Quirico, fue elegido para sucederle. La elección de los obispos visigodos recaía habitualmente en el monarca, sin perjuicio de que tuviera en cuenta la voluntad del clero $^{33}$, y la del metropolitano de la capital sería un asunto especialmente relevante para la monarquía. Wamba eligió a Julián, a pesar de sus incómodos orígenes. ¿Qué pudo pesar en esa elección? Sin lugar a dudas, la larga asociación entre ambos clérigos, en la que posiblemente Gudila, por su origen familiar, fuese el destinado a alcanzar altos cargos, mientras Julián sería el adjunto en la sombra, el posibilitador intelectual de que Gudila brillase con todo el fulgor de su aristocrático nacimiento. Otros factores probables fueron las prisas, no pudiendo quedarse vacante la sede toledana durante mucho tiempo, la ausencia de otro candidato idóneo, y por supuesto, la determinación personal del mismo Julián a lograr ese fin; este último aspecto implicaba cierto compromiso de apoyo al monarca.

La elección de Julián por Wamba pasando por alto sus orígenes judíos no impidió la aparente traición de ese pocos meses después. Ciertamente la participación de Julián en lo que bien parece haber sido un derrocamiento de Wamba por el conde Ervigio, el 14 de octubre 680, no está probada, y Julián tiene y ha tenido defensores entre los historiadores, sobre todo los más recientes ${ }^{34}$. Un primer dato a tener en cuenta es que Julián era cercano a Ervigio desde antes de 680. Le dedicó dos de sus obras, una de las cuales, de forma reveladora, aún en su época de comes: el Libellus de Divinis Iudiciis $^{35}$, hoy perdido. Aunque nada nos permite acusar al obispo de narcotizar a Wamba para imponerle la penitencia mientras estaba sin sentido, lo que sí hizo Julián fue administrar la penitencia a Wamba en un momento en que este "se dirigía hacia el desenlace de una necesidad inevitable» ${ }^{36}$, es decir, se encontraba (en apariencia) in articulo mortis, y probablemente inconsciente: esto obligó al rey a abandonar el siglo, y por tanto el poder, en cuanto recuperó la conciencia.

32 Cuius corpusculum in monasterio sancti Felicis, quod est Cauensi in uillula dedicatum, dilectissimi sociii sui exibitione honorifice requiescit humatum. (Felix Toletanus, Vita s. Iuliani, 3, ed. V. Yarza Urquiola 2014, 10). Sobre el monasterio Cabense, véase Moreno Martín, La arquitectura monástica hispana, 213. Se ha propuesto localizarlo en la margen izquierda del Tajo, frente al sur de la ciudad, en las inmediaciones de la ermita Santa María del Valle (Aparicio Bastardo 1993, 12).

33 El nombramiento de los obispos por el monarca, heredado de Roma y presente también en la Francia merovingia, aparece por primera vez en Hispania en 599 (Conc. Barc. II, c. 3, ed. Vives 1963, 159-160), es mencionado en la correspondencia de Braulio de Zaragoza e Isidoro de Sevilla como un trámite normal (pero influenciable), y también aparece, de forma oblicua, en el concilio de Mérida de 666 (Conc. Emer., c. 4, ed. Vives 1963, 328). Cf. de Mañaricúa 1966, 87-114.

34 Murphy 1952, 2 y De Jong 1999, 373-374.

35 Item libellum de diuinis iudiciis, ex sacris uoluminibus collectum, in cuius principio est epistola ad dominum Eruigium comitatus sui tempore pro eodem libello directa (Felix Toletanus, Vita s. Iuliani, 10, ed. V. Yarza Urquiola 2014,14$)$.

36 Idem enim Vuamba princeps, dum ineuitabilis necessitudinis teneretur euentu, suscepto religionis debito cultu et uenerabili tonsurae sacrae signaculo, mox per scripturam definitionis suae hunc inclitum dominum nostrum Eruigium post se praelegit regnaturum et sacerdotali benedictione unguendum (Conc. Tol. XII, c. 1, CCH, vol VI, 151-152). 
El XII Concilio de Toledo, celebrado en enero de 681, refiere lo ocurrido el mes de octubre anterior en su canon primero, y en su canon 2 resuelve la problemática de la penitencia administrada sin pedirla el enfermo, pero sin relacionarla con acontecimientos concretos. Se ha defendido (De Jong 1999, 374, n. 1) que la Crónica de Alfonso III (Chronica Adefonsi Regis III Legionensis, 2) que acusa a Ervigio de haber drogado a Wamba opera una simple asociación de ideas basada en estos dos decretos; pero el mismo orden de los cánones del XII Concilio induce a pensar que los obispos consideraban el asunto del canon 2 una cuestión de Estado, no de disciplina eclesiástica, lo cual revela su relación con la caída de Wamba ${ }^{37}$. La necesidad de legislar sobre el particular debió de surgir de que algunos acusaran al obispo de actuar sin pedirlo el monarca, y posiblemente de mala fe. Recordemos, aunque se suele pasar por alto, que Julián no presidió ese concilio, que suscribió en segundo lugar después de su tocayo Julián de Sevilla, metropolitano de mayor antigüedad; pero el estudio del estilo de los dos primeros cánones indica «sin la menor duda» que el autor de la Historia Wambae «intervino de forma decisiva en su redacción» (Martín Iglesias 2010b, 155-156), lo cual confirma la estrecha relación del canon 2 con lo ocurrido en el octubre anterior. Podemos incluso intuir que Julián tuvo que rendir cuentas a sus coepíscopos, ya que el canon 2 condena a un año de excomunión a los clérigos que hubieran administrado la penitencia a un enfermo sin que él fuera consciente y lo requiriera, a menos de poder probar que el mismo, amonestado para recibirla, hiciera un gesto con las manos o cualquier otro signo evidente de anuencia ${ }^{38}$. Esta formulación deja atisbar la argumentación de que, posiblemente, Julián presentara en su defensa ante los demás obispos; en todo caso, lejos de sancionarle de ninguna manera, la asamblea adoptó la medida que otorgaba la primacía a la sede toledana $^{39}$, ańadiendo un aumento de poder efectivo al prestigio que esta ya ostentaba como sede regia.

La responsabilidad de Julián en lo que sí parece un golpe de Estado no se limita a la administración muy discutible de la penitencia que abocaba Wamba a la abdicación. Según se desprende del canon 1, el docto Julián, experto en derecho canónico, aceptó como buena la supuesta voluntad de Wamba de que el conde Ervigio le sucediera en el reino y procedió a su unción real a los pocos días $^{40}$, contraviniendo así dos normas canónicas sobre la sucesión al trono visigodo ${ }^{41}$. El XII Con-

37 El canon 3 decide que se levantará la excomunión cuando el rey haya vuelto a admitir a los culpables a su mesa, armonizando así la política eclesiástica de exclusión de culpables con la regia; el 4 gestiona (y anula) la creación por Wamba de obispados en sitios donde nunca los había habido antes. Los 5 y 6 ya encaran problemas de disciplina eclesiástica, los siguientes (7-11) de disciplina de los laicos; en cambio los cánones 1, 3 y 4 atañen a las relaciones entre los obispos y el poder regio, lo que induce a pensar que el 2 también tiene que ver con dichas relaciones, aunque no lo formule explícitamente.

38 ...sacerdos tamen qui non sentienti neque petenti ausu temerario paenitentiam dederit, neque se exhortatum eius qui paenitentiam accepit, manuum indiciis, uel quibuslibet aliis euidentibus significationibus inuitatum fuisse probauerit, unius anni excommunicationis sententiae subiaebit. (Conc. Tol. XII, c. 1, CCH, vol.VI, 158).

39 Conc. Tol. XII, c. 6. Cf. Martin 2003, 245-247.

40 Según el Laterculus Regum Visigothorum, 46-47 ( $M G H A A$, XIII, 468), Wamba recibió la penitencia el domingo por la noche, Ervigio asumió el poder al día siguiente, lunes, y la unción real se aplazó al siguiente domingo. Si a Julián esos acontecimientos nocturnos le tomaron por sorpresa, hay que admitir que reaccionó con celeridad y eficacia.

41 Conc. Tol. IV, c. 1 y Conc. Tol. VIII, c. 10. Bien es cierto que, en 649, Chindasvinto incumplió el primer canon al asociar a su hijo al trono, pero el segundo reafirmó esta norma nada más morirse él, en 653, exigiendo explícitamente el asenso de todos los obispos y magnates para la elección real (Abhinc ergo et deinceps ita erunt in regni gloriam perficiendi rectores, ut aut in urbe regia aut in loco ubi princeps decesserit cum pontificum maiorumque palatii omnimodo eligantur adsensu, non forinsecus aut conspiratione paucorum aut rusticarum plebium seditioso tumultu, CCH, vol.V, 428). Así fue cómo, de acuerdo al mismo Julián, Wamba sucedió a Recesvinto en 672 (Historia Wambae, III, ed. Levison 1910, 502). Por supuesto, que a su vez Ervigio en 687 nombrase a su sucesor de la misma anticanónica manera que Wamba (Laterculus Regum Visigothorum, 49) no justifica a posteriori lo ocurrido en 680 . 
cilio cotejó los documentos presentados (por Julián, sin duda) que manifestaban la voluntad de Wamba, pero limitó su aceptación a autentificar los documentos en cuestión, sin pronunciarse sobre el hecho consumado de una unción ejecutada antes de la asamblea conciliar ${ }^{42}$. Como siempre, las actas conciliares nos ocultan los debates, tal vez intensos, mantenidos por la asamblea, asamblea que, insisto, no presidía Julián en esta ocasión ${ }^{43}$. En todo caso, y aun a sabiendas de que los decretos conciliares visigodos a menudo se infringían, queda bastante surrealista el celo con el que los obispos examinaron la documentación presentada, frente a su mutismo en torno a la conformidad del proceso seguido.

Existen suficientes fundamentos, por tanto, para defender que Julián de Toledo ayudó a su amigo el conde Ervigio en su ascenso al trono, traicionando al monarca que le había hecho metropolitano sin atender a sus orígenes judíos, y con el que — todo indica - se llevaba muy bien hasta entonces ${ }^{44}$. El historiador de hoy no tiene acceso a la conciencia del prelado, pero incluso si él estimaba tener buenos motivos para traicionar (y la promesa de una actuación firme contra los judíos ciertamente pudo ser uno), en los diez años que le quedarían de vida le sería difícil obviar, para sí, esa traición, del mismo modo que no podía obviar la mancha de su origen familiar, por muy disimulada que estuviera bajo la púrpura metropolitana. La asociación de judeidad y traición aparece con mucha más nitidez en su obra histórica, hasta el punto de que las dos nociones resultan intercambiables.

Lo que se suele llamar "obra histórica» de Julián de Toledo es en realidad un dossier de cuatro piezas (MGH SS Rer. Merov., V, 486-535) de naturaleza dispar, cuya temática común es la rebelión de las provincias Narbonense (Gallia) y Tarraconense contra el rey Wamba pocos meses después de su accesión al trono, en 673: una Epistula de desafío del dux rebelde, Paulus; una Historia Wambae regis que no relata el reinado de Wamba, sino únicamente su primer año, marcado por la sublevación; una Insultatio Galliae (invectiva contra la provincia gala); y un Iudicium que da cuenta del juicio celebrado después de haber sofocado la rebelión.

Julián escribió la Historia y tal vez también alguno de los otros tres documentos; al menos los reescribió y agrupó él mismo (Martínez Pizarro 2005, 78-85). Las que nos interesan aquí son la Historia y la Insultatio, dado que ambas mencionan, aunque de forma poco explícita, la presencia de judíos en la provincia Narbonense sublevada contra el rey. Constituyen uno de los principales argumentos de quienes afirman que las comunidades judías eran especialmente poderosas en la provincia gala del reino visigodo a finales del siglo viI ${ }^{45}$.

En primer lugar, y pese a que algún autor se haya posicionado en contra de esa idea (García Herrero 1998), conviene señalar que la atribución de la Insultatio uilis storici in tyrannidem Galliae a Julián de Toledo es aceptada, hoy día, por la gran mayoría de los especialistas ${ }^{46}$, que subrayan

42 En este caso, tal vez anómalo, la unción real no revelaba al rey, no era meramente declarativa, tal como Julián la describió en su Historia Wambae (II, 12-16), sino que era constitutiva del poder real, aunque la redacción del c.1, probablemente por él mismo, antepusiera la preelección divina al rito, como en el caso de Wamba. Cf. Deswarte 2010, 360.

43 Como bien remarca Collins 2004, 104, las actas de Toledo XII fueron confirmadas decreto por decreto dos años después, en la siguiente asamblea conciliar (Conc. Tol. XIII, c.9), lo que no se produjo en ninguna otra ocasión. Ese trámite excepcional pudo parecer necesario debido a la persistencia de debates entre los obispos con posterioridad a enero de 681 .

44 Murphy 1952, 10 resalta que la relación entre Wamba y Julián era a todas luces buena, y por su parte lo considera un argumento suficiente para rechazar la eventualidad de una traición de Julián.

45 Cf. Martin 2019, 61-62.

46 De Jong 1999, 384; Martínez Pizarro 2005, 80; Martín Iglesias 2010b, 163; Deswarte 2014, 72-73. 
además su relación temática y estilística con la Historia Wambae. Mucho más breve que esa, la Insultatio es una invectiva (uituperatio), una pieza retórica agresiva dirigida en segunda persona a la Gallia, es decir, a la provincia visigoda de Narbonense, y que recuerda, como en espejo, la Laus Spaniae antepuesta por Isidoro de Sevilla a su Historia de los Godos ${ }^{47}$. También existe un paralelo muy sugestivo con la Altercatio Ecclesiae et Synagogae, un texto anónimo del siglo v en el que la Sinagoga aparece como una madre criminal derrotada por la Iglesia (especialmente los capítulos 10-11). Una primera explicación a la asociación entre la Gallia y los judíos es, sin ir más lejos, esa probable fuente de inspiración de Julián de Toledo.

Después de denunciar brevemente, en su primer capítulo, que la Gallia se ha ido apoyando más en la amistad de los judíos que en la de los seguidores de Cristo ${ }^{48}$, el texto desarrolla este motivo en el segundo capítulo:

Y aun cometiendo esos delitos, no te estremeces con el horror de tanto crimen, sino que encima de todo esto estás dispuesta a asociarte con judíos, a cuya infidelidad, si prestas atención, reconoces que se han pasado ya tus hijos, ya que los que ante ti brillaban con el título de cristianos, está probado que se han pasado a la perfidia de los hebreos; pues siempre te encomendabas a sus dictámenes, cuando sabías que Dios había reprobado ya sus corazones. Y ¿cómo has podido venerar los infaustos santuarios de los judíos, en los que tan insistentemente habías puesto el empeño por tu salvación? Reconoce, desgraciada, reconoce lo que has hecho. Que te sea suficiente el haber perdido la memoria en medio de la fiebre. Ahora ya, superado el estigma de las fiebres, reconócete como nodriza del escándalo, sustento del mal, madre de blasfemos, madrastra de infieles, hijastra de litigios, alimento de prostitutas, antro de traición, fuente de perfidia, asesina de almas. ${ }^{49}$

Con un afán alimentado por la considerable escasez de fuentes sobre las comunidades judías visigodas de los siglos vi y viI, los historiadores suelen interpretar esta diatriba en sentido literal. Pero es muy poco aconsejable utilizar fragmentos sacados de contexto para construir un discurso histórico. La Insultatio es una pieza retórica basada en un acontecimiento, la rebelión de 673, sobre la que no da ninguna información concreta, más que, supuestamente, el poder que ostentarían los judíos en la provincia de Galia. No nombra ni personajes, ni lugares, ni sucesos precisos. Se desarrolla en torno a dos imágenes entrelazadas: por una parte la personificación de la Gallia como mujer pecadora, adúltera, que engañó a su marido el rey Wamba con el usurpador Paulus (particularmente Insultatio, III); por otra, una alegoría que la asimila al miembro enfermo de un cuerpo político, del que el rey aparece en unas ocasiones como la cabeza y en otras, en el papel de médico. Esta alegoría se corresponde con una visión política muy arraigada en la cultura latina de los si-

47 Cf. McCormick 1986, 326. El estudio literario de la Insultatio por Martínez Pizarro 2005, 153-163, es imprescindible.

48 ...Iudaeorum potius quam fidelium Christi amicitiis incubabas (Insultatio, I, ed. W. Levison, 526).

$49 \mathrm{Nec}$ tamen ista faciens tanti immanitate facinoris contremescis, sed super haec omnia ludaeorum consortiis animaris, quorum etiam infidelitatem, si libens adtendis, iam in tuis transisse filiis recognoscis, dum hii, qui in te christianitatis titulo praefulgebant, ad Hebraeorum probati sunt transisse perfidiam; eorum enim te semper iu- diciis committebas, quorum iam a Deo reprobata corda cognoueras. Et qualiter ludaeorum a te poterant infausta uenerari sacraria, in quibus tam instanter salutis tuae conlocaueras curam? Agnosce, misera, agnosce quid feceris! Sufficiat tibi inter febres amisisse memoriam. Nunc iam, depulsa febrium labe, nutricem te scandali recognosce, fomitem mali, matrem blasfemantium, nouercam infidelium, negotiorum priuignam, prostibulorum materiam, proditionis speleum, fontem perfidiae, animarum interemptricem (Insultatio Galliae, II, ed. Levison 1910, 526-527). 
glos vi y viI, la del cuerpo y los miembros (Martínez Pizarro 2005, 104-109), y Julián insiste especialmente en su dimensión mórbida. El final de la Insultatio, por ejemplo, recurre a la misma imagen de una herida purulenta y necesitada de intervención médica que el prefacio del De comprobatione sextae aetatis a Ervigio, ya mencionado ${ }^{50}$ : en el primer caso se trata de desarraigar cualquier brote de rebelión contra Wamba, en el segundo, de apartar por la fuerza (ferro) el judaísmo del organismo político visigodo.

Hay que destacar, por último, que la Insultatio hace caso omiso de la Tarraconense, que sin embargo, según la Historia, se sumó a la rebelión de la Gallia ${ }^{51}$ : el autor necesita orientar su ira hacia un solo territorio, presentado como una sola mujer, según la tradición antigua retomada por Isidoro de Sevilla en la Laus Spaniae, o como una provincia periférica, una parte corporal (miembro) separada del tronco peninsular (Martínez Pizarro 2005, 108).

En la trama puramente retórica de la Insultatio corre el mismo hilo conductor que en la Historia y el Iudicium, mucho más factuales: el de la falta a la fe, la perfidia ${ }^{52}$. En latín visigodo, esta palabra tiene el doble sentido de traición política e infracción religiosa, la segunda generalmente imputada, a partir de la conversión de los arrianos, a los judíos. La asimilación de fides política y fides religiosa en las concepciones visigodas es bien conocida desde los trabajos de Carlos Petit ${ }^{53}$, y queda ilustrada en la ley de Recesvinto, antes señalada, que prohibía el testimonio judicial a los judíos ${ }^{54}$. Aunque se observa principalmente en las fuentes normativas, los textos literarios que nos ocupan aquí son otro ejemplo de esta asimilación conceptual, la cual es suficiente motivo para la aparición de judíos, tanto en la Insultatio como en la Historia.

Una frase de la Historia Wambae constituye, en mi opinión, la clave de lectura que conviene usar para entender la presencia de Iudaei en el relato de la sublevación narbonense:

Y así Paulus, habiendo adoptado la mente de Saulo, en tanto que no quiso ser un auxilio para la fe, buscó ser un estorbo contra la fe. ${ }^{5}$

Como un pasaje bíblico, esta frase tiene varios niveles de lectura en torno a la polisémica palabra fides. En sentido literal, el viaje exageradamente lento del general Paulus hacia la Galia sublevada le sume en la tibieza, y de ahí en la traición: fides remite entonces al juramento de fidelidad anteriormente prestado al rey godo. En sentido alegórico, Paulus es Pablo de Tarso en el camino de Damasco, pero emprende ese camino al revés y termina siendo mentalmente un judío perseguidor de los cristianos: la fides contra la que arremete es, por supuesto, la fe cristiana. Como un judío (que no era) y como un traidor (que sí fue), Pablo es, por tanto, llamado perfidus, por ejemplo en el título de la carta de desafío: Incipit epistola Pauli perfidi, qui tyrannice rebellionem in Gallias fecit Wambani principis magni. A partir de ese momento, la Galia sublevada se puebla de judíos.

50 Insultatio Galliae, IX, ed. Levison 1910, 529. Cf. supra y Martínez Pizarro 2005, 107, n.72.

51 Omisión notada por Deswarte 2014, 75.

52 Las palabras perfidus y perfidia vuelven insistentemente en los cuatro textos y sobre todo en sus títulos, así como los derivados de tyrannus, 'usurpador': cf. Martínez Pizarro 2005, 82 y 98-100.
53 Especialmente Petit 1995, 843-932.

${ }^{54} L V$, XII, 2, 10, cf. supra n.15.

55 Sicque Paulus in Sauli mente conuersus, dum pro fide noluit proficere, officere conatus est contra fidem (Iulianus Toletanus, Historia Wambae, VII, ed. Levison 1910, 506). 
La Historia Wambae que precede a la Insultatio solo encierra dos alusiones a los judíos, una de las cuales resulta realmente enigmática si no se adopta nuestra interpretación. Al final de la narración, Wamba se hace con la victoria y entra triunfalmente en Narbona, capital de la provincia:

Allí, después de pasarles revista, dispersó las guarniciones de combatientes, arrancó por completo las raíces de la rebelión, expulsó a los judíos y nombró para las ciudades gobernantes más humanos, a través de quienes la ofensa de tanto mal se suavizó, y la tierra mancillada por tanta basura, purgada por un nuevo bautismo de juicios, obtuvo el perdón. ${ }^{56}$

Entender que Wamba expulsó a los judíos de Narbona sería un error. Si algún caso de expulsión se dio en la contemporánea Francia merovingia, los reyes visigodos, en cambio, procuraron convertir a «sus» judíos por todos los medios, pero siempre manteniendo el control sobre ellos. Expulsarlos era la peor forma de tenerlos controlados. Por otra parte, los judíos no desempeñan ningún papel en el relato de Julián, y no se entiende la relación entre la victoria del rey y su supuesta expulsión. Lo más lógico es que el autor se refiera en ese punto a judíos en el sentido de traidores, es decir, a las autoridades urbanas (cristianas) que se habían sumado a la rebelión, y a las que el rey, tras su victoria, sustituye por unos gobernantes leales.

La segunda alusión de la Historia, de tono y temáticas muy afines a los de la Insultatio, es más fácil de resolver:

¿Qué no había en ella de cruel o lúbrico, siendo como era nido de conspiradores, señal de perfidia, obscenidad en las obras, fraude en los negocios, juicio comprado y, lo que es peor que todo, un prostíbulo de judíos blasfemos contra nuestro propio Salvador y Señor?57

Uniendo en una sola fórmula la infidelidad matrimonial (prostíbulo) y religiosa (judíos blasfemos), Julián se coloca claramente en el plano metafórico: los judíos en cuestión no son reales. «Nuestro propio Salvador y Señor» puede asimismo remitir tanto a Dios (con mayúsculas en la traducción) como al príncipe (sin ellas): una vez más, se puede entender la frase de dos maneras distintas.

Al final de la Historia Wambae, la equivalencia entre los judíos que traicionan a Dios y los Galli que traicionan al rey godo se resuelve en un «bautismo de juicios» (iudiciorum baptisma, en el pasaje anteriormente citado). Por esta razón el texto del Iudicium cierra la serie de documentos agrupados por Julián: el juicio a los traidores actúa como el sacramento del bautismo, que purifica a los judíos y los reúne con Dios. De este modo, el conjunto documental compilado por Julián representa el proceso de perdición y salvación de la humanidad, encarnada alternativamente en un $d u x$ felón y en una provincia rebelde.

Terminaré con unos apuntes acerca de la fecha de composición de la Historia Wambae, cuestión que no se debería desgajar de la de su naturaleza. Si tradicionalmente se ha situado su escritura poco después de los acontecimientos de $672 / 3$, lo cual era coherente con considerarla una obra his-

56 Lecta illic praesidia bellatorum dimittit, radices ab ea omnis rebellionis detersit, ludaeos abegit, clementiores urbibus rectores instituit, per quos utique tanti mali placaretur offensa et constuprata tantis sordibus terra, nouo iudiciorum baptismate depurgata, remitteretur ad ueniam (Historia Wambae, XXVIII, ed. Levison 1910, 524).
57 Quid enim non in illa crudele uel lubricum, ubi coniuratorum conciliabulum, perfidiae signum, obscenitas operum, fraus negotiorum, uenale iudicium et, quod peius his omnibus est, contra ipsum saluatorem nostrum et dominum Iudaeorum blasfemantium prostibulum habebatur? (Historia Wambae, V, ed. Levison 1910, 504). 
tórica rozando el panegírico (así Teillet 1986), hoy los autores suelen aceptar la tesis que la ubica durante el reinado de Ervigio (680-688) (García López 1993), o incluso a principios del de Égica, entre 688 y 690 (García Herrero 1998). Que Julián la haya redactado después del derrocamiento de Wamba y probablemente después de su muerte (fechada antes de noviembre 683) modifica el papel que otorga a su protagonista, que ya no puede ser su dedicatorio implícito. Collins subrayó que por más que la materia del texto sea histórica, su naturaleza es claramente didáctica, y el público pensado por Julián pudo ser el de los jóvenes miembros de la aristocracia susceptibles de acceder, algún día, a la realeza visigoda (Collins 1992). En este contexto, Wamba se convierte en un personaje literario cuya relación personal con Julián en la vida real deja de ser relevante. Aun así, no es imposible que la composición de la obra se insertase en un momento de desengańo del prelado con Ervigio, momento que podemos situar cerca de la redacción del De comprobatione sextae aetatis, al final de su reinado. Su prefacio al rey, ya mencionado, concluye con unas líneas finales cuyo valor conminatorio queda mal disimulado:

Crea Vuestra Celsitud que, habiéndose mostrado digna protectora de la causa de Cristo, encontrará segura salvación en el Juicio hacia el que se encamina. En efecto, cuando el día del Juicio aparezca resplandeciente, se tomará en consideración vuestra obra, al menos siempre que, oh piadosísimo príncipe, oprimas con valentía los cuellos de los enemigos de Cristo con el yugo de la servitud del Señor, y levantes con fuerza el estandarte de la fe cristiana. ${ }^{58}$

Recordándole al rey que él también sería objeto de juicio, como los rebeldes de la Galia, Julián deja adivinar que el celo de Ervigio contra los judíos ya no era el que había sido. Parece lógico pensar que el bautizo forzoso ordenado en 681 no diera los frutos esperados, por motivos comprensibles de falta de medios de represión. Julián sin duda presumía de haber bautizado él mismo a algún judío, por ejemplo al tal Restituto al que mandó de mensajero a su amigo Idalio de Barcelona hacia 688 o 689, con su nueva obra Prognosticon futuri saeculi ${ }^{59}$. Pero las medidas antijudaicas adoptadas por Égica pocos años después indican que quedaban todavía muchos judíos sin bautizar y muchos bautizados a la fuerza profanando la religión impuesta, una situación que no podía gustarle al obispo de Toledo.

Para Julián de Toledo como para sus contemporáneos, la judeidad se asemejaba a una mácula que permanecía más allá del bautizo, y su caso personal no debió de ser ninguna excepción. Consiguió superar socialmente esa tara inicial, alcanzó una posición desde la que influir en el rumbo político del reino godo, y la aprovechó para apoyar lo que le parecía primordial: la persecución de los judíos. Esta obsesión puede explicar que haya colaborado en la destitución de Wamba, al que luego representó como un monarca ideal lidiando con judíos y traidores. Y es que para él, judaísmo y traición no eran sino dos vertientes de la misma infidelidad: traicionar la fe jurada al monarca y traicionar la fe abrazada mediante bautismo forzado eran marcas de la misma perfidia.

58 Vestra igitur Celsitudo, quae se patronam causae Christi exhibuit, credat se omnimodo, ipso ad iudicium ueniente, saluari. Erit enim tunc respectus operis uestri, cum dies iudicii manifestus effulserit. Si modo tamen, o piissime princeps, et ualenter inimicorum Christi colla ingo seruitutis dominicae comprimas, et uexilla fidei Christia- nae potenter attollas (Julianus Toletanus, De comprobatione sextae aetatis adversus Judaeos, ed. Hilgarth 1976, 147-148).

59 Adueniens namque quidam iudaeus, nomine Restitutus, quasi brutum, ut ita dixerim, animal... (Epistula Idalii ad Julianum, ed. Hillgarth 1976, 4). 
Posiblemente Julián haya contemplado en sí mismo los estigmas de la traición y de la judeidad con el mismo horror, y haya llegado a identificarse hasta cierto punto con el usurpador, retrotraído a su identidad de Saulo, cuya traición denunció en la Historia Wambae. Esta idea, al menos, arroja una luz nueva sobre la penitencia a la que emplaza la personificación de la Gallia en las últimas líneas de la Insultatio (Insultatio Galliae, IX, ed. Levison, 529), así como sobre el calificativo de «vil» que le otorga en el explicit... pero se otorga también a sí mismo en el íncipit ${ }^{60}$. Del mismo modo que Valerio del Bierzo y hacia la misma época, los últimos ańos del siglo viI, Julián de Toledo aparecería así como el autor y a la vez el objeto, o uno de los objetos posibles, de una combinación de textos que admitía varias lecturas ${ }^{61}$.

Para Julián, los judíos eran indudablemente reales: con total seguridad, bautizó al menos a uno, asignándole el nombre cristiano de Restituto y usándole a continuación para sus recados. Pero los judíos de la Historia Wambae y de la Insultatio Galliae no tenían más materialidad que el personaje magnificado, transformado en elemento de exemplum, del rey Wamba, al que, años atrás, Julián había traicionado en la vida real. La utilización de esos escritos para documentar las comunidades judías de Narbonense en la alta Edad Media resulta, por tanto, insostenible.

\section{FUENTES}

Altercatio ecclesiae et synagogae [CCSL 69A], ed. J. N. Hillgarth, M. Conti, Turnhout: Brepols, 1999.

Chronica Muzarabica a. 754, ed. J. Gil en: Chronica Hispana saeculi VIII et IX [CCCM 65], Turnhout: Brepols, 2018, 325-382.

Chronica Adefonsi Regis III Legionensis, ibid., 383-433.

Colección Canónica Hispana (= CCH), ed. G. Martínez Díez, F. Rodríguez, vol. IV-VI, Madrid: CSIC, 1984-2002.

Felix Toletanus, Vita sancti Iuliani, en: Iuliani Toletani Opera pars II [CCSL 115-B], ed. V. Yarza Urquiola, Turnhout: Brepols, 2014, 7-14.

Hildefonsus Toletanus, De viris illustribus, en: Ildefonsi Toletani episcopi opera omnia [CCSL 114-A], ed. C. Codoñer, Turnhout: Brepols, 2007.

Hildefonsus Toletanus, De virginitate Sanctae Mariae, en: Ildefonsi Toletani episcopi opera omnia [CCSL 114-A], ed. V. Yarza Urquiola, Turnhout: Brepols, 2007.

Isidorus Hispalensis, De laude Spaniae, ed. C. Rodríguez Alonso, Las Historias de los Godos, Vandalos y Suevos de Isidoro de Sevilla, León: Centro de Estudios e Investigación San Isidoro, 1975, 168-171.

Julianus Toletanus, Historia Wambae regis [MGH SS Rer. Merov., V], ed. W. Levison, Hannover-Leipzig, $1910,486-535$.

Julianus Toletanus, De comprobatione sextae aetatis adversus Judaeos, en: Sancti Iuliani Toletanae Sedis Episcopi Opera. Pars I [CCSL 115], ed. J. N. Hillgarth, Turnhout: Brepols, 1976, 141-212.

Laterculus Regum Visigothorum [MGH AA, XIII (Chronica Minora, V)], ed. Th. Mommsen, Berlin, 1898, 464-469.

Liber Iudiciorum siue Lex Visigothorum (= LV) [MGH Leges, I, 1], ed. K. Zeumer, Hannover-Leipzig, 1902, 33-456.

Vitas Sanctorum Patrum Emeritensium [CCSL 116], ed. A. Maya Sánchez, Turnhout: Brepols, 1992.

60 Incipit Insultatio uilis storici in tyrannidem Galliae (Insultatio Galliae, ed. Levison 1910, 526).
61 Martínez Pizarro 2005, 83-85 compara de forma muy sugestiva el dossier "histórico» de Julián con el corpus autobiográfico de Valerio del Bierzo. 


\section{BiBLIOGRAFÍA}

Aparicio Bastardo, J. A., i993, "Notas para la aproximación al estudio de las iglesias de mozárabes en la urbe toledana", Anaquel de Estudios Árabes 4, 9-24.

Blaise, A., 1975, Dictionnaire latin-français des auteurs du Moyen Âge, Turnhout: Brepols.

Collins, R., 1992, "Julian of Toledo and the Education of Kings in Late Seventh-Century Spain», en: Id., Law, Culture and Regionalism, Aldershot, Variorum, III.

Collins, R., 2004, Visigothic Spain 409-711, Oxford: Blackwell.

De Jong, M., 1999, "Adding insult to injury: Julian of Toledo and his Historia Wambae», en: P. Heather (ed.), The Visigoths From the Migrations Period to the $7^{\text {th }}$ Century. An Ethnographic Perspective, Woodbridge: Boydell Press, 373-402.

Deswarte, Th., 2010, «La trahison vaincue par la charité : Julien de Tolède et les rebelles», en: M. Billoré, M. Soria (eds.), La trahison au Moyen Âge. De la monstruosité au crime politique (V $V^{e} X V^{e}$ s.), Rennes: PUR, 353-368.

Deswarte, Th., 2014, «Une nation inachevée : le royaume de Tolède», en: Nation et nations au Moyen Âge : XLIVe congrès de la SHMESP (Praque, 23 mai-26 mai 2013), Paris: Publications de la Sorbonne, 63-78.

Diccionario de Autoridades, 1726-1739, Madrid: Real Academia Española.

DumÉzil, B., 2005, Les racines chrétiennes de l'Europe. Conversion et liberté dans les royaumes barbares, VeVIII siècles, Paris: Fayard.

García Herrero, G., 1998, "Sobre la autoría de la Insultatio y la fecha de composición de la Historia Wambae», en: Jornadas internacionales: "Los Visigodos y su mundo», Arqueología, Paleontología y Etnografía, IV, Madrid: Cdad. de Madrid, Consejería de Educación y Cultura, 115-125.

García Iglesias, L., 1978, Los judios en la Hispania antigua, Madrid: Cristiandad.

García López, Y., 1993, «La cronología de la 'Historia Wambae'», Anuario de Estudios Medievales 23, 121-139.

García López, Y., 1996, Estudios críticos y literarios de la Lex Wisigothorum, Alcalá de Henares: Universidad de Alcalá.

García Moreno, L. A., 1993, Los judios de la España antigua. Del primer encuentro al primer repudio, Madrid: RIALP.

González SAlinero, R., 2000, Las conversiones forzosas de los judios en el reino visigodo, Roma: CSIC.

KInG, P. D., 1972, Law and Society in the Visigothic Kingdom, Cambridge: Cambridge University Press.

Laham Cohen, R., 2012, «El De fide catholica de Isidoro de Sevilla en el marco de la disputa adversus Iudaeos», en: A. V. Neyra, G. Rodríguez (dir.), ¿Qué implica ser medievalista? Prácticas y reflexiones en torno al oficio del historiador, Mar del Plata: Universidad Nacional de Mar del Plata y Sociedad Argentina de Estudios Medievales, 5-21.

Laham Cohen, R., \& Pecznik, C., 2016, «Iudaei et iudaei baptizati en la ley de los visigodos», Anuario de la Escuela de Historia 28, 141-169.

Linage Conde, A., 1973, Los orígenes del monacato benedictino en la Peninsula Ibérica, León: Centro de Estudios e Investigación San Isidoro, CSIC.

MacCormick, M., 1986, Eternal Victory. Triumphal Rulership in Late Antiquity, Byzantium, and the Early Medieval West, Cambridge: Past and Present Publications.

Mañaricúa, A. E. de, 1966, «El nombramiento de obispos en la España visigótica y musulmana», Scriptorium Victoriense 13, 87-114.

Martin, C., 2003, La Géographie du pouvoir dans l'Espagne visigothique, Lille: Septentrion.

Martin, C., 2011, "Le Liber Iudiciorum et ses différentes versions», Mélanges de la Casa Velázquez. Nouvelle série 41 (2), 17-34.

Martin, C., 2017, «Les juifs visigothiques, un peuple hérétique», en: Les juifs et la nation au Moyen Âge, Revue de l'histoire des religions 234-2, 315-335.

Martin, C., 2019, "Los judíos de Narbonense a finales del siglo viI: peste, persecución y articulación territorial», en: XLV Semana Internacional de Estudios Medievales de Estella-Lizarra, Rostros judios del Occidente medieval, 17/20 de julio de 2018, Pamplona, 53-68. 
Martín Iglesias, J. C., 2010a, "Chronica Muzarabica anni 754», en: C. Codoñer (coord.), La Hispania visigótica y mozárabe. Dos épocas en su literatura, Salamanca: Universidad de Salamanca, 244-251.

Martín Iglesias, J. C., 2010b, "Julián de Toledo», en: C. Codoñer (coord.), La Hispania visigótica y mozárabe. Dos épocas en su literatura, Salamanca: Universidad de Salamanca, 155-172.

Martín Iglesias, J. C., 2011, «Relatos hagiográficos sobre algunos obispos de la España medieval en traducción: Ildefonso y Julián de Toledo (BHL 3917 y 4554), Isidoro de Sevilla (BHL 4488) y Froilán de León (BHL 3180)», Veleia 28, 209-242.

Martínez Pizarro, J., 2005, The Story of Wamba. Julian of Toledo's Historia Wambae regis, Washington: Catholic University of America Press.

Moreno Martín, F. J., 2011, La arquitectura monástica hispana entre la Tardoantigüedad y la alta Edad Media [British Archaeological Reports 2287], Oxford: Archaeopress.

Murphy, F. X., 1952, "Julian of Toledo and the Fall of the Visigothic Kingdom in Spain», Speculum 27, $1-21$.

Niermeyer, J. F., 1976, Mediae Latinitatis Lexicon Minus, Leiden: Brill.

OrLANDIS, J., 1980, «Hacia una mejor comprensión del problema judío en el Reino visigodo-católico de España», en: Gli ebrei nell'alto medioevo [Settimane di Studio del Centro Italiano di Studi sull'Alto Medioevo 26], Spoleto, 149-196.

Oxford Latin Dictionary, 1968, Oxford: Oxford University Press.

Peтtт, C., 1995, “Iustitia” y "Iudicium” en el reino de Toledo. Un estudio de teología jurídica visigoda», en: La giustizia nell'alto medioevo (sec. V-VIII) [Settimane di Studio del Centro Italiano di Studi sull'Alto Medioevo 42], Spoleto, 843-932.

Teillet, S., 1986, «L'Historia Wambae est-elle une œuvre de circonstance ?», Antigüedad y cristianismo 3: Los Visigodos. Historia y Civilización. Actas de la Semana Internacional de Estudios Visigóticos (Madrid-Toledo-Alcalá de Henares, 21-25 de octubre de 1985, 415-424. 